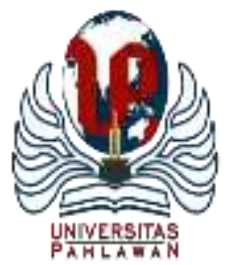

Edukatif : Jurnal Ilmu Pendidikan Volume 3 Nomor 6 Tahun 2021 Halm 4126 - 4133

EDUKATIF: JURNAL ILMU PENDIDIKAN

Research \& Learning in Education

https://edukatif.org/index.php/edukatif/index

\title{
Pengaruh Pelatihan Senam Aerobic terhadap Penurunan Kadar Lemak Ibu-Ibu di Club Keke Studio di Kota Lubuklinggau
}

\author{
Desy Juwita Utami ${ }^{1}$, Wawan Syafutra ${ }^{2 凶}$, Hengky Remora $^{3}$ \\ STKIP PGRI Lubuklinggau, Indonesia ${ }^{1,2,3}$ \\ E-mail : $\underline{\text { desyutami.2599@gmail.com }}{ }^{1},{\text { putra.awan328@ } \text { gmail.com }^{2}, \text { por remora@yahoo.com }}^{3}$
}

\begin{abstract}
Abstrak
Penelitian ini bertujuan untuk mengetahui seberapa besar pengaruh latihan senam aerobic terhadap penuruna kadar lemak ibu-ibu di Klub Keke Studio Kota Lubuklinggau. Metode penelitian eksprimen, sampel dalam penelitian berjumlah 30 orang ibu-ibu yang melakukan senam aerobic. Pengujian ini menggunakan analisa normalitas dan paired sample t-test. Hasil penelitian diketahui bahwa pengolah data dengan program SPSS 21 bahwa data dinyatakan distribusi normal, pengujian hipotesis didapatkan bahwa thitung sebesar 21.525 dengan nilai $t_{\text {tabel }}$ sebesar 1,699, maka $t_{\text {hitung }}>t_{\text {tabel }}$ maka Ho ditolak dan Ha diterima yang artinya Ada pengaruh latihan senam aerobic terhadap penurunan kadar lemak ibu-ibu di Klub Keke Studi Kota Lubuklinggau.
\end{abstract}

Kata kunci: Latihan Senam, Kadar Lemak

\begin{abstract}
This study aims to determine how much influence aerobic exercise training has on reducing women's fat levels at the Keke Studio Club, Lubuklinggau City. In this experimental research, the sample in the study amounted to 30 mothers who did aerobic exercise. This test uses normality analysis and paired sample t-test. The results showed that the data processing using the SPSS 21 program stated that the data were normally distributed, hypothesis testing was found that $t_{\text {count }}$ was 21,525 with a $t_{\text {table }}$ value of 1,699 , then $t_{\text {count }}>t_{\text {table }}$ then Ho was rejected and Ha was accepted, which means that there is an effect of aerobic exercise on reducing fat levels of women at the Lubuklinggau City Study Keke Club.
\end{abstract}

Keywords: Gymnastics Exercise, Fat Content

Copyright (c) 2021 Desy Juwita Utami, Wawan Syafutra, Hengky Remora

$\triangle$ Corresponding author:

Email : putra.awan328@gmail.com

DOI : https://doi.org/10.31004/edukatif.v3i6.1395

ISSN 2656-8063 (Media Cetak)

ISSN 2656-8071 (Media Online) 
4127 Pengaruh Pelatihan Senam Aerobic terhadap Penurunan Kadar Lemak Ibu-Ibu di Club Keke Studio di Kota Lubuklinggau - Desy Juwita Utami, Wawan Syafutra, Hengky Remora

DOI: https://doi.org/10.31004/edukatif.v3i6.1395

\section{PENDAHULUAN}

Olahraga adalah aktivitas fisik yang dilakukan secara terencana untuk berbagai tujuan, antara lain mendapatkan kesehatan, kebugaran, rekreasi, pendidikan, dan prestasi (Budiasih, Utaminingtyas, 2018). Studi WHO pada faktor-faktor risiko menyatakan bahwa kurangnya aktivitas fisik seperti duduk dalam jangka waktu yang lama saat bekerja adalah salah satu dari sepuluh penyebab kematian dan kecacatan di dunia. Lebih dari dua juta kematian setiap tahun disebabkan oleh kurangnya bergerak atau beraktivitas fisik mereka (Achmad, 2000).

Wanita dengan lemak tubuh lebih dari $30 \%$ dan pria dengan lemak tubuh lebih dari $25 \%$ dianggap mengalami obesitas (Indah, 2016). Kelebihan lemak adalah kenyataan yang dapat memicu terjadinya banyak penyakit. Meningkatnya kolesterol dalam darah memicu penyempitan atau penyumbatan pembuluh darah di otak, penyempitan pada pembuluh darah di jantung ataupun mungkin juga penyempitan dan penyumbatan pembuluh darah di sekitar kaki (Purwono, Joni, 2014).

Menurut Grace Judio, dalam (Jonni, 2003), "tujuan makan ialah untuk memuaskan lapar, memenuhi kebutuhan nutrisi, dan kesehatan". Sekarang ini, tujuan seseorang untuk makan tidak mempertimbangkan rasa lapar saja tetapi lebih mempertimbangkan kepuasan diri (Utomo, 2012). Pola makan yang tidak teratur dan kurang seimbang, membuat masalah yang besar terhadap kesehatan. Perubahan pola makan tradisonal ke modern seperti fast food yang banyak mengandung kalori, lemak dan kolestrol menunjukkan dampak dengan meningkatnya masalah gizi lebih (obesitas) (Nuerye, Indah Putri, 2020). Tentunya jika pola hidup seperti ini dilakukan dalam jangka panjang akan menyebabkan masalah yang besar terhadap kesehataan. Sehingga menimbulkan penumpukkan lemak di dalam tubuh yang menyebabkan kelebihan berat badan, menurut William Sears dalam (Djoko Pekik Irianto, 2000), "lemak adalah komponen dasar dalam hormon-hormon yang penting dan bagian yang berharga dalam membuat sel, terutama sel-sel darah merah". Lemak sendiri terbagi menjadi dua jenis yaitu lemak jenuh dan lemak tidak jenuh (Alim, Abdul, 2011).

Kelebihan berat badan memicu penurunan fungsi tubuh, gerak menjadi lambat, sampai-sampai malas hanya untuk memindahkan diri ke tempat lain (Leane Suniar, 2000). Untuk itu perlu dilakukan upaya pencegahan agar 3 tidak menimbulkan lemak yang berlebihan. Salah satu solusi terbaik ialah melakukan olahraga dan pengaturan pola makan yang seimbang (Wicaksono, B., Budiyono, B., \& Setiani, 2016). Sejatinya banyak jenis olahraga yang dapat dilakukan untuk proses penuruan kadar lemak dalam tubuh, salah satunya olahraga berjenis aerobik yaitu seperti jalan, lari, bersepeda atau pun senam. Aeorbik merupakan olahraga yang mudah dilakukan dan ringan dalam gerakannya. Salah satu bentuk olahraga aerobik yang rekreatif ialah senam aerobik (Katch, 2010). Keberadaan kadar lemak dalam tubuh memiliki peranan sebagai cadangan energi, melindungi organ-organ tubuh dari benturan-benturan dan penyimpanan vitamin yang larut dalam lemak. Dengan melakukan olahraga yang teratur dan mengatur pola makan dapat memperoleh bentuk tubuh yang baik, kebugaran tubuh dan sedikit kadar lemak dalam tubuh (M. Syukur Zulbandi Sitepu, James Tangkudung, 2020).

Bentuk latihan olahraga yang dapat dilakukan untuk mengendalikan keberadaan kadar lemak tubuh dan menjaga tingkat kesehatan adalah latihan olahraga yang bersifat aerobik, di antaranya jalan kaki, jogging, bersepeda, renang, senam aerobik dan lainnya (bakri, 2020). Dari jenis latihan aerobik yang dikemukakan, salah satunya adalah senam aerobik. Menurut (Jonni, 2003) mengemukakan, bahwa senam aerobik adalah latihan yang dilakukan untuk membakar lemak sambil memperbaiki kekencangan otot yang dipimpin oleh pelatih berpengalaman secara bersama-sama dengan diiringi musik yang sesuai dengan irama/gerakan untuk anggota tubuh yang bergerak (Fajar Sriwahyuniati, 2009).

Dewasa ini banyak sekali program-program latihan aerobik yang ditawarkan, diantaranya adalah senam aerobic (Kurniawati, 2000). Senam aerobik merupakan latihan yang menggunakan seluruh otot terutama otototot besar, dengan gerakan terus menerus, berirama, progresif dan berkelanjutan (Brian J. Sharkey, 2010). 
4128 Pengaruh Pelatihan Senam Aerobic terhadap Penurunan Kadar Lemak Ibu-Ibu di Club Keke Studio di Kota Lubuklinggau - Desy Juwita Utami, Wawan Syafutra, Hengky Remora

DOI: https://doi.org/10.31004/edukatif.v3i6.1395

Pada pelaksanaannya, senam aerobik menggunakan iringan musik yang antara lain berguna untuk meningkatkan motivasi latihan, pengaturan waktu latihan, dan kecepatan latihan (Kusmana, 2007).

Cara mengantisipasi kegemukan tersebut, saat ini banyak ibu-ibu yang mengikuti klub Keke Studio yang menawarkan berbagai macam program (Putri, E., \& Syahrastani, 2020). Kegiatan berolahraga di klub Keke Studio sekarang ini bukan lagi menjadi suatu kebutuhanmelainkan juga menjadi suatu gaya hidup tersendiri bagi ibu-ibu di Kota Lubuklinggau. Berolahraga di klub Keke Studio dapat menjadi gaya hidup karena selain mendapatkan tubuh yang sehat, setiap orang juga dapat memiliki penampilan yang menarik serta di klub Keke Studio menawarkan berbagai macam jenis olahraga yang dapat menurunkan berat badan salah satunya adalah senam aerobik.

"Senam aerobik merupakan salah satu bentuk latihan yang bagus karena selain menyenangkan, susuan intensitas lainnya dilakukan dengan zona latihan, durasi antara 30-45 menit, dan frekuensi latihan kira-kira 2-3 hari seminggu cukup untuk menaikan sedikit fungsi kardiovaskular dan kesehatan serta daya tahan otot ke keadaan yang lebih baik lagi. (Katch 2010 : 5). Menurut (Alim, Abdul, 2011). Selain 5 membuat awet muda, manfaat dari aerobik bagi tubuh sangat banyak, yakni menjaga stamina tubuh, kebugaran tubuh, mengencangkan otot-otot tubuh atau membentuk tubuh menjadi kelihatan indah, melancarkan peredaran darah serta mengurangi kelebihan lemak dalam tubuh (Susmanto Y, 2010). Perkembangan olahraga senam aerobic ini sudah sedemikian maju, khususnya senam aerobic yang sangat diminati ibu-ibu di Kota Lubuklinggau ini. Di Keke Studio senam aerobic terdapat 30 peserta senam aerobic dan 2 instruktur yang bernama Lidia dan Jemi . Selain itu, kelebihan berolahraga di klub Keke Studio dapat mencegah kegemukan, membentuk otot dan memperbaiki tonus. Senam aerobik juga telah dapat memelihara elastisitas dan kesehatan kulit sehingga tidak cepat keriput dan tampak awet muda membentuk tubuh menjadi lebih proposional, indah dipandang dan menimbulkan daya tarik, dimana komposisi tubuh menunjukkan perbandingan kumpulan otot, tulang, lemak dan cairan di dalam tubuh (Indiyani, Puji, 2010).

Selain itu di Klub Keke Studio memiliki jadwal latihan yang teratur yaitu pada hari senin , rabu dan jum'at dan berlokasi di Jalan. Amula Rahayu,Tanah Periuk, Lubuklinggau Selatan II, Kota Lubuklinggau. sehingga dapat dicapai hasil yang lebih efektif dan maksimal.

Kategori senam yang dipakai yaitu memakai Hight Impact, Low Impact dan Body Language. Hight Impact adalah terdapat lompatan-lompatan, karena tujuanya untuk meningkatkan power dan kardiovaskuler latihan ini dilakukan dengan intensitas tinggi .Low Impact adalah gerakan yang cocok untuk pemula yaitu tidak memekai lompatan tujuannya untuk daya tahan atau stamina (Endurance ). Sedangkan Body Language adalah gerakan yang sering kali ditambakan dengan kontraksi otot . dengan melakukan kontraksi bagian pinggul dan perut, maka akan meningkatkan kekuatan otot perut, bokong hingga otot-otot dasar rongga panggul (Dewantari, N. M. and Ambartana, 2018).

Berdasarkan hasil Observasi peneliti di Klub Keke Studio Kota Lubuklinggau, di dapati permasalahan yaitu tingginya kelebihan berat tubuh ibu-ibu yang melewati ambang batas ideal tubuh. Hal ini dibuktikan dari hasil observasi dengan mengukur tinggi dan menimbang berat tubuh yang bersangkutan. Hasilnya 30 ibu-ibu mengalami over weight atau kelebihan berat tubuh.

Selain itu berdasarkan hasil wawancara pada ibu-ibu di Klub Keke Studio Kota Lubuklinggau yang mengalami over weight, gaya hidup seperti konsumsi makan-makanan cepat saji, snack-snack, minumminuman bersoda, maupun yang mengandung kaffein tinggi merupakan hal yang wajib setiap harinya. Berdasarkan hasil wawancara peneliti pada tanggal 22 Maret 2021 kepada instruktur Jemi dan Lidia yang dilakukan di Keke Studio telah di dapatkan data banyak di temukan peserta dari ibu-ibu yang berbeda profesi dan status sosial lainnya terdapat adanya ibu rumah tangga dan kebanyakan ibu-ibu terkhusus yang di amula rahayu yang senam disana. Di Klub Keke Studio senam tersebut hanya untuk kaum wanita saja dan jumlah peserta senam disana mencapai 30 orang peserta senam aerobic. 
4129 Pengaruh Pelatihan Senam Aerobic terhadap Penurunan Kadar Lemak Ibu-Ibu di Club Keke Studio di Kota Lubuklinggau - Desy Juwita Utami, Wawan Syafutra, Hengky Remora

DOI: https://doi.org/10.31004/edukatif.v3i6.1395

\section{METODE PENELITIAN}

Metode penelitian ini adalah penelitian eksperimen karena penelitian ini memerlukan perlakuan. Perlakuan yang dilakukan pada variabel bebas dan dilihat hasilnya pada variabel terikatnya. Sedangkan menurut Sugiyono (2010: 107), penelitian eksperimen merupakan metode penelitian yang digunakan untuk mencari pengaruh perlakuan tertentu terhadap yang lain dalam kondisi yang terkendalikan. Desain yang digunakan dalam penelitian ini adalah pre-test post-test control group design.

Cara pakai alat pengukur kadar lemak

1. Jelaskan prosedur kepada responden

2. Minta kepada responden untuk membuka baju sedikit atau menyingsingkan baju lengan untuk mengukur lemak tubuh di bicep.

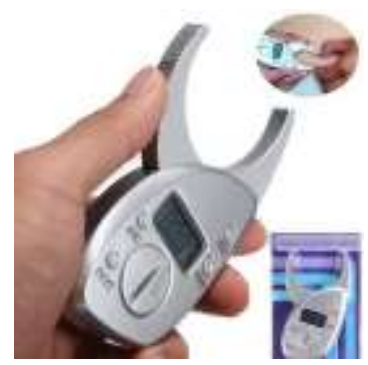

Gambar 1. Alat Pengukur kadar lemak

(Sumber: Halodoc.com)

Kategori Kadar Lemak Tubuh Wanita.

Lemak yang ada di dalam tubuh manusia dapat dihitung sesuai dengan masing-masing orang, mulai dari tinggi badan, berat badan, usia, jenis kelamin, konsumsi sehari-hari serta berdasarkan lipatan lemak yang ada di bawah kulit (Gallagher, et al, 2015: 696; Akindele, et al, 2016: 15).

Menurut Widiyanto (2013), paired sample t-test merupakan salah satu metode pengujian yang digunakan untuk mengkaji keefektifan perlakuan, ditandai adanya perbedaan rata-rata sebelum dan rata-rata sesudah diberikan perlakuan. Dasar pengambilan keputusan untuk menerima atau menolak Ho pada uji ini adalah sebagai berikut.

1. Jika $t$ hitung $>t$ tabeldanprobabilitas (Asymp.Sig) $<0,05$, maka Ho ditolakdan Ha diterima.

2. Jika $t$ hitung $<\mathrm{t}$ table dan probabilitas (Asymp.Sig) $>0,05$, maka Ho diterima dan Ha ditolak.

Proseduruji paired sample t-test (Siregar, 2013):

a. Menentukan hipotesis; yaitu sebagai berikut:

b. Menentukan level of significant sebesar $5 \%$ atau 0,05

c. Menentukan criteria pengujian

d. Penarikan kesimpulan berdasarkan pengujian hipotesis

\section{HASIL DAN PEMBAHASAN PENELITIAN}

Uji Normalitas adalah sebuah uji yang dilakukan dengan tujuan untuk menilai sebaran data pada sebuah kelompok data atau variabel, apakah sebaran data tersebut berdistribusi normal ataukah tidak.Uji Normalitas berguna untuk menentukan data yang telah dikumpulkan berdistribusi normal atau diambil dari populasi normal.Metode klasik dalam pengujian normalitas suatu data tidak begitu rumit.Berdasarkan pengalaman empiris beberapa pakar statistik, data yang banyaknya lebih dari 30 angka (n > 30), maka sudah dapat diasumsikan berdistribusi normal.Biasa dikatakan sebagai sampel besar. Adapun hasil pengolahan data menggunakan program SPSS 21 disajikan dalam bentuk tabel dibawah ini: 
4130 Pengaruh Pelatihan Senam Aerobic terhadap Penurunan Kadar Lemak Ibu-Ibu di Club Keke Studio di Kota Lubuklinggau - Desy Juwita Utami, Wawan Syafutra, Hengky Remora

DOI: https://doi.org/10.31004/edukatif.v3i6.1395

Tabel 1

Hasil Pengujian Normalitas Data Penelitian Tests of Normality

\begin{tabular}{|c|c|c|c|c|c|c|}
\hline \multicolumn{7}{|c|}{ Tests of Normality } \\
\hline & \multicolumn{3}{|c|}{ Kolmogorov-Smirnova } & \multicolumn{3}{|c|}{ Shapiro-Wilk } \\
\hline & Statistic & $\mathrm{df}$ & Sig. & Statistic & df & Sig. \\
\hline Pretest & .141 & 30 & .133 & .938 & 30 & .080 \\
\hline Postest & .144 & 30 & .114 & .946 & 30 & .133 \\
\hline
\end{tabular}

a. Lilliefors Significance Correction

Sumber: Hasil Pengolahan Data, SPSS 21 Tahun 2021

Berdasarkan hasil pengujian SPSS 21 dengan pengujian normalitas data penelitiaan, diketahui bahwa pada kolom Shapiro-Wilk dengan krititeria bahwa jika nilai sig>0.05 maka data dapat dinyatakan berdistribusi normal, maka dengan demikian hasil pengujian didapatkan nilai X_Pretest sig sebesar $0.080>0.050$ dan X_Protes ebesar 0.133>0,05 maka dapat disimpulkan data telah berdistribusi normal dan dilakukan pengujian Paires Sample t-test selanjutnya.

Paired sample t-test merupakan salah satu metode pengujian yang digunakan untuk mengkaji keefektifan perlakuan, ditandai adanya perbedaan rata-rata sebelum dan rata-rata sesudah diberikan perlakuan. Dasar pengambilan keputusan untuk menerima atau menolak Ho pada uji ini adalah sebagai berikut.

1. Jika $t$ hitung $>\mathrm{t}$ tabel dan probabilitas (Asymp.Sig) $<0,05$, maka Ho ditolak dan Ha diterima.

2. Jika thitung $<\mathrm{t}$ tabel dan probabilitas (Asymp.Sig) $>0,05$, maka Ho diterima dan Ha ditolak.

Prosedur uji paired sample t-test (Siregar, 2013):
a. Menentukan hipotesis; yaitu sebagai berikut:
b. Menentukan level of significant sebesar $5 \%$ atau 0,05
c. Menentukan kriteria pengujian
d. Penarikan kesimpulan berdasarkan pengujian hipotesis

Adapun hasil pengujian dan pengolahan data disajikan dalam bentuk tabel dibawah ini:

Tabel 2

Data Hasil Pengujian Paired Samples Statistik

\begin{tabular}{lllrrr}
\hline \multicolumn{5}{c}{ Paired Samples Statistics } \\
\hline \multirow{2}{*}{ Pair 1 } & & Mean & N & Std. Deviation & Std. Error Mean \\
\cline { 2 - 6 } & Postest & 26.1300 & 30 & 3.58369 & .65429 \\
\hline
\end{tabular}

Sumber: Hasil Pengolahan Data, SPSS 21 Tahun 2021

Berdasarkan tabel di atas dapat diketahui bahwa nilai Mean Pretest X sebessar 26.130 dan lebih besar dari Protest yakni sebesar 23.840, maka hal ini menandakan terdapat perbedaan sebelum dan sesudah pelaksanaan senam aerobic di Klub Keke Studio Kota Lubuklinggau, jumlah responden N 30 maka responden dalam penelitian ini berjumlah 30 orang ibu -ibu yang melakukan senam di Klub Keke Studio Kota Lubuklinggau, serta standar deviation pretest X sebesar 3.5837 dan Protest X sebesar 3.3862, maka terdapat perbedaan standar deviation.

Tabel 3

Data Hasil Pengujian Paired Samples Correlations

\begin{tabular}{lccccr}
\hline \multicolumn{7}{c}{ Paired Samples Correlations } \\
\hline \multicolumn{7}{c}{ N } & Correlation & Sig. \\
\hline Pair 1 & Pretest \& Postest & 30 & & .988 & .000 \\
\hline
\end{tabular}

Sumber: Hasil Pengolahan Data, SPSS 21 Tahun 2021 
4131 Pengaruh Pelatihan Senam Aerobic terhadap Penurunan Kadar Lemak Ibu-Ibu di Club Keke Studio di Kota Lubuklinggau - Desy Juwita Utami, Wawan Syafutra, Hengky Remora

DOI: https://doi.org/10.31004/edukatif.v3i6.1395

Berdasarkan tabel di atas dapat diketahui bahwa nilai Correlation sebesar 988 maka dapat dinyatakan terdapat hubungan antara latihan senam aerobic terhadap penurunan kadar lemak sebesar $98.8 \%$, hal ini menunjukkan hubungan yang kuat antar latihan senam dan penurunan kadar lemak oleh ibu-ibu senam aerobic, sedangkan Sig sebesar 0,000<0,005 sehingga dapat dinyatakan hubungan yang signifikan antara latihan senam terhadap penurunan kadar lemak, ibu-ibu senam aerobic Klub Keke Studio Kota Lubuklinggau.

\section{Tabel 4}

Data Hasil Pengujian Paired Samples Test Paired Samples Test

\begin{tabular}{|c|c|c|c|c|c|c|c|c|c|}
\hline \multicolumn{10}{|c|}{ Paired Samples Test } \\
\hline & & \multicolumn{5}{|c|}{ Paired Differences } & \multirow[t]{3}{*}{$\mathrm{t}$} & \multirow[t]{3}{*}{ df } & \multirow[t]{3}{*}{ Sig. (2-tailed) } \\
\hline & & \multirow[t]{2}{*}{ Mean } & \multirow[t]{2}{*}{$\begin{array}{c}\text { Std. } \\
\text { Deviation }\end{array}$} & \multirow{2}{*}{$\begin{array}{c}\text { Std. } \\
\text { Error } \\
\text { Mean }\end{array}$} & \multicolumn{2}{|c|}{$\begin{array}{l}\text { 95\% Confidence Interval of the } \\
\text { Difference }\end{array}$} & & & \\
\hline & & & & & Lower & Upper & & & \\
\hline \multirow{2}{*}{ Pair 1} & Pretest - & 2.2900 & .58271 & .1063 & 2.07241 & 2.5075 & 21.52 & 29 & .000 \\
\hline & Postest & 0 & & 9 & & & 5 & & \\
\hline
\end{tabular}

Sumber: Hasil Pengolahan Data, SPSS 21 Tahun 2021

Berdasarkan tabel di atas dapat diketahui bahwa nilai bahwa nilai Mean Pretest X - Protest X sebesar 2.2900 maka selisih tersebut menunjukkan selisih yang cukup rendah karena tidak mengalami nilai (-) sehingga selisih masih di nilai positif, sedangkan Standar Deviation sebear 0,5827 antara latihan senam terhadap penurunan kadar lemak, ibu-ibu senam aerobic Klub Keke Studio Kota Lubuklinggau, standar eror tingkat kesalahan dalam penilaian adalah sebesar $0.1064<1$ sehingga standar eror yang rendah.

Pengujian hipotesis dengan menggunakan paired sample t-test dengan hipotesis yang akan diuji kebenaranya yakni

1. Hipotesis alternative $(\mathrm{Ha})$

Ada pengaruh latihan senam aerobic terhadap penurunan kadar lemak ibu-ibu di Klub Keke Studi Kota Lubuklinggau.

2. Hipotesis nol (Ho)

Tidak ada pengaruh senam aerobic terhadap penurunan kadar lemak ibu-ibu di Klub Keke Studio Kota Lubuklinggau .

Dengan standar pengujian adalah Jika $t$ hitung $>\mathrm{t}$ tabel dan probabilitas (Asymp.Sig) $<0,05$, maka Ho ditolak dan Ha diterima.Jika $t$ hitung $<\mathrm{t}$ tabel dan probabilitas (Asymp.Sig) > 0,05, maka Ho diterima dan Ha ditolak, maka hasil pengujian analisa SPSS 21 menggunakan perhitungan pretest $X$ dan postest $X$ didapatkan nilai thitung sebesar 21.525 dengan nilai ttabel sebesar $1,699(\mathrm{~N}=30$ penentuan ttabel $\mathrm{N}-1=30-1=29$ dengan standar $0.05 \%$ ) berdasarkan hasil olah data dan kriteria maka dapat diketahui nilai thitung $>$ ttabel maka Ho ditolak dan Ha diterima yang artinya Ada pengaruh latihan senam aerobic terhadap penurunan kadar lemak ibu-ibu di Klub Keke Studi Kota Lubuklinggau.

\section{KESIMPULAN}

Kelebihan berat badan memicu penurunan fungsi tubuh, gerak menjadi lambat, sampai-sampai malas hanya untuk memindahkan diri ke tempat lain. Untuk itu perlu dilakukan upaya pencegahan agar 3 tidak menimbulkan lemak yang berlebihan. Salah satu solusi terbaik ialah melakukan olahraga dan pengaturan pola makan yang seimbang. Sejatinya banyak jenis olahraga yang dapat dilakukan untuk proses penuruan kadar lemak dalam tubuh, salah satunya olahraga berjenis aerobik yaitu seperti jalan, lari, bersepeda atau pun senam. Aeorbik merupakan olahraga yang mudah dilakukan dan ringan dalam gerakannya. Salah satu bentuk olahraga aerobik yang rekreatif ialah senam aerobik. Berdasarkan hasil olah data dan kriteria maka dapat diketahui nilai thitung>ttabel maka Ho ditolak dan Ha diterima yang artinya Ada pengaruh latihan senam aerobic terhadap penurunan kadar lemak ibu-ibu di Klub Keke Studi Kota Lubuklinggau. 
4132 Pengaruh Pelatihan Senam Aerobic terhadap Penurunan Kadar Lemak Ibu-Ibu di Club Keke Studio di Kota Lubuklinggau - Desy Juwita Utami, Wawan Syafutra, Hengky Remora

DOI: https://doi.org/10.31004/edukatif.v3i6.1395

\section{UCAPAN TERIMA KASIH}

Terimakasih dosen pembimbing saya bapak Wawan Syafutra, M.Pd. dan Bapak Hengky Remora yang telah membantu saya dalam menyelesaikan proposal hingga skripsi saya hingga selesai dan terimaksi buat pemilik studio senam keke lubuklinggau dan selaku instruktur jemi yang telah membantu saya dalam menjalankan peneliian di studio keke .

\section{DAFTAR PUSTAKA}

Achmad. (2000). Ilmu Gizi untuk Mahasiswa dan Profesi di Indonesia. Jakarta: Dian Rakyat.

Alim, Abdul, dkk. (2011). Pengaruh Aktivitas Aerobik Terhadap Perubahan Penurunan Lemak Pada Sanggar Segar. Universitas Negeri Yogyakarta.

Bakri, Siska Zamhar. (2020). Pengaruh Latihan Senam Aerobik terhadap Penurunan Berat Badan, Persentase Lemak Tubuh dan Peningkatan Massa Otot. Journal of Sport Science, 5(2), 219-233. https://doi.org/https://doi.org/10.24036/sporta.v5i2.151

Brian J. Sharkey. (2010). Kebugaran dan Kesehatan. Jakarta: PT Raja Grafindo Persada.

Budiasih, Utaminingtyas, dkk. (2018). Efektifitas Senam Aerobic Intensitas Sedang terhadap Persen Lemak Tubuh dan Berat Badan pada Mahasiswi Overweight di Jurusan Gizi Poltekkes Kemenkes Semarang. JURNAL RISET GIZI, 6(2), 79-84. https://doi.org/https://doi.org/10.31983/jrg.v6i2.4292

Dewantari, N. M. and Ambartana, I. W. (2018). Pengaruh Komposisi Diet Dan Senam Aerobik Terhadap Penurunan Berat Badan, Gizi Indonesia. Persagi: Persatuan Ahli Gizi Indonesia, 40(2), 59-68. https://doi.org/10.36457/gizindo.v40i2.239

Djoko Pekik Irianto. (2000). Dasar-dasar Latihan Kebugaran. Yogyakarta: Lukman Offset.

Fajar Sriwahyuniati. (2009). Laporan Kegiatan PPM: Pelatihan Senam Aerobik Produk FIK UNY untuk Instruktur Senam FOMI Kota Yogyakarta. UNY.

Indah, D. (2016). Pengaruh Latihan Senam Aerobik terhadap Penurunan Kadar Lemak Tubuh Anggota Senam Sanggar Kebugaran Muslimah Centre Padang. Jurnal Pendidikan Rokania, 1(1), 1-9.

Indiyani, Puji, dkk. (2010). Pengaruh Latihan Fisik; Senam Aerobik terhadap Penurunan Kadar Gula Darah Pada Penderita DM Tipe 2 di Wilayah Puskesmas Bukateja Purbalingga. Nurse Media Journal of Nursing, 1(2), 49-99. https://doi.org/https://doi.org/10.14710/nmjn.v1i2.717

Jonni. (2003). Senam Aerobic. Universitas Negeri Padang.

Katch. (2010). Senam Aerobic. Jakarta: Kementrian Pendidikan dan Kebudayaan.

Kurniawati, N. (2000). Pelatihan interval meningkatkan attention span dari pada pelatihan aerobik pada remaja putri usia 18-21 tahun. Universitas Udayana.

Kusmana. (2007). Intensitas Latihan Beban. Aquaculture Journal, 2(1), 22-26.

Leane Suniar. (2000). Cara Aman Mencegah Kegemukan. Jakarta: PT. Inti Sari Mediatama.

M. Syukur Zulbandi Sitepu, James Tangkudung, \& W. P. (2020). Pengaruh Latihan Senam Aerobik dan Motivasi Berolahraga terhadap Penurunan Persentase Lemak Tubuh. Jurnal Penjaskesrek, 7(1), 45-59. https://doi.org/https://doi.org/10.46244/penjaskesrek.v7i1.1008

Nuerye, Indah Putri, dkk. (2020). Pengaruh Senam Aerobik dan Motivasi Latihan Terhadap Penurunan Persentase Lemak Tubuh. JTIKOR (Jurnal Terapan Ilmu Keolahragaan), 5(2), 108-119. Retrieved from

https://www.researchgate.net/publication/348795098_Pengaruh_Senam_Aerobik_dan_Motivasi_Latiha n_Terhadap_Penurunan_Persentase_Lemak_Tubuh

Purwono, Joni, dkk. (2014). Penggunaan Media Audio-Visual Pada Mata Pelajaran Ilmu Pengetahuan Alam 
4133 Pengaruh Pelatihan Senam Aerobic terhadap Penurunan Kadar Lemak Ibu-Ibu di Club Keke Studio di Kota Lubuklinggau - Desy Juwita Utami, Wawan Syafutra, Hengky Remora

DOI: https://doi.org/10.31004/edukatif.v3i6.1395

di Sekolah Menengah Pertama Negeri 1 Pacitan. Jurnal Teknologi Pendidikan Dan Pembelajaran, 2(2), 127-144. Retrieved from https://www.e-jurnal.com/2015/01/penggunaan-media-audio-visual-padamata.html?m=1

Putri, E., \& Syahrastani, S. (2020). Pengaruh Senam Aerobik Mix Impact Terhadap Penurunan Kadar Lemak Tubuh. Sport Science, 18(2), 71-82.

https://doi.org/http://sportscience.ppj.unp.ac.id/index.php/jss/article/view/19

Susmanto Y. (2010). Senam Aerobic. Jakarta: Kementrian Pendidikan dan Kebudayaan.

Utomo, G. T. (2012). Pengaruh Latihan Senam Aerobik Terhadap Penurunan Berat Badan, Persen Lemak Tubuh dan Kadar Kolesterol pada Remaja Putri Penderita Obesitas di Sanggar Senam Studio 88 Salatiga. Universitas Negeri Semarang.

Wicaksono, B., Budiyono, B., \& Setiani, O. (2016). Faktor Risiko Kejadian Iritasi Mata pada Pengguna Kolam Renang X di Kota Semarang. Jurnal Kesehatan Masyarakat (Undip), 4(4), 852-858. Retrieved from https://ejournal3.undip.ac.id/index.php/jkm/article/view/14377 